\title{
Restoration of the annual flood pulse in Breton Sound, Louisiana, USA: habitat change and nekton community response
}

\author{
Bryan P. Piazza $^{1, *}$, Megan K. La Peyre ${ }^{2}$ \\ ${ }^{1}$ School of Renewable Natural Resources, Louisiana State University Agricultural Center, Baton Rouge, Louisiana 70803, USA \\ ${ }^{2}$ USGS Louisiana Fish and Wildlife Cooperative Research Unit, School of Renewable Natural Resources, \\ Louisiana State University Agricultural Center, Baton Rouge, Louisiana 70803, USA
}

\begin{abstract}
Riverine pulse events are hypothesized to benefit estuarine nekton resources by making high-quality habitat available for exploitation; however, few studies focus on the actual nekton use of this ephemerally flooded habitat during the flood pulse event. We evaluated the effects of pulsed freshwater flow on nekton density, biomass, diversity and community assembly through 2 winter/spring (February and March) experimental high-flow riverine discharge events in the upper reaches of the Breton Sound estuary, Louisiana, USA in 2005. Nekton were caught with a $1 \mathrm{~m}^{2}$ drop sampler at flooded vegetated marsh sites in areas both receiving (inflow) and not receiving (reference) pulsed freshwater flow. Inflow marsh sites had significantly greater water depth and were flooded for over twice as long as reference marshes. Significantly higher nekton density and biomass were found at flooded inflow marsh sites than reference marsh sites. Nekton communities were similar and dominated by estuarine resident species (Palaemonetes paludosus, Heterandria formosa, Gambusia affinis, Lucania parva, Poecilia latipinna, Cyprinodon variegatus). The C-score metric (EcoSim) indicated that while initial colonization (1 to $3 \mathrm{~d}$ ) of flooded sites was random, species assembly following longer-term flooding ( 7 to $10 \mathrm{~d}$ ) suggested non-random colonization ( $p<0.0001$; EcoSim) and supported the coexistence principle. Despite significant coexistence, subtle differences in community assembly were seen among the resident guild, with evidence of segregation driven by water depth $(\mathrm{p}=0.002$; canonical correspondence analysis $)$.
\end{abstract}

KEY WORDS: Nekton · Community assembly · Water depth · Freshwater diversion · Drop sampler Estuary $\cdot$ Louisiana

Resale or republication not permitted without written consent of the publisher

\section{INTRODUCTION}

A general consensus exists among scientists and resource managers that the quantity and timing of freshwater flow to an estuary is central to the maintenance of estuarine resources (Alber 2002). Significant evidence documenting the negative effects of reduced freshwater inflow from human activities such as dams, channels or water withdrawal has led to numerous attempts to restore freshwater inflow, with the goal of enhancing estuarine function (Loneragan \& Bunn 1999, Gillanders \& Kingsford 2002). In estuaries influenced by large rivers, restoration of freshwater inflow is accomplished largely through the restoration of the annual floodpulse event. Physical and chemical changes associated with restored freshwater flow can have significant effects on estuarine nekton by inundating the surrounding floodplain and making high-quality habitat available for exploitation (Gillanders \& Kingsford 2002). It has been hypothesized that this habitat flooding may be a key factor linking estuaries to high levels of secondary production, and, more recently, that fish may provide an essential link in the movement of energy within and through the estuarine system via the horizontal transport of allochthonous energy off the marsh surface and into subtidal habitats (Kneib 2000). While 
there have been a number of studies examining the effects of riverine flooding on fisheries of forested floodplain ecosystems (e.g. see Winemiller \& Jepsen 1998), few studies in estuarine environments have focused on fisheries-related effects during riverine flood pulses.

Overflow events, common during seasonal flood pulses, transfer large amounts of sediment and nutrients to the floodplain and affect the spatial and temporal variability of environmental conditions (salinity, sediment, and physiochemistry), which in turn may influence species composition, abundance, distribution and primary and secondary production (Alber 2002). Large freshwater flows, characteristic of flood pulse events, may influence the biotic community structure and production both by positioning dynamic habitat (salinity) relative to static physical habitat (Browder \& Moore 1981) and by making ephemeral habitat available for exploitation (Rozas 1995, Kneib 2000). Both mechanisms result in strong associations with fish community structure (Kushlan 1976, Kneib 2000).

Natural delta subsidence and sea level rise coupled with anthropogenic alteration of hydrologic flow regimes, severance of river flooding, and canal dredging have combined to create coastal wetland loss rates in Louisiana of 64 to $91 \mathrm{~km}^{2}$ per year (Barras et al. 2003). A key component of Louisiana's coastal restoration program involves re-establishing fluvial connectivity to the delta through the construction of 5 active freshwater diversions, ranging in discharge from 7 to $297 \mathrm{~m}^{3} \mathrm{~s}^{-1}$. One of the largest diversion projects in Louisiana, the Caernarvon Freshwater Diversion, dramatically influences the supply of fresh water, sediment, and nutrients into the Breton Sound estuary (Lane et al. 2004, Snedden et al. 2007a) and provides a unique opportunity to examine the effects of freshwater flow on estuarine fisheries.

We studied the effects of freshwater pulsing from the Caernarvon structure on estuarine nekton by investigating the ephemeral habitat use resulting from flooding. Specifically, we examined the effects of freshwater flow on estuarine nekton in marsh habitat of the upper Breton Sound estuary, Louisiana, during 2 seasonal floodpulse events in 2005 by comparing nekton abundance, biomass, diversity, and community assembly in treatment (inflow) and reference (no flow) areas.

\section{MATERIALS AND METHODS}

Study area. Breton Sound is a 271000 ha estuary in the Mississippi River deltaic plain in southeast Louisiana (Fig. 1). It is microtidal and consists of bays, lakes, bayous, canals, and fresh, intermediate, brackish, and saline marsh types. The upper estuary is separated geographically and hydrologically by Bayou Terre Aux Boeufs, a relic Mississippi River distributary.

This study took place in the upper Breton Sound basin, in emergent marshes subject to flooding from the Caernarvon Freshwater Diversion structure (Caernarvon). Prior to the construction of Caernarvon, the estuary had experienced significant land loss (>18 000 ha; Barras et al. 2003) due to isolation from riverine input and natural and anthropogenic habitat alteration (USACE Caernarvon Freshwater Diversion fact sheet; www.mvn.usace.army.mil/prj/caernarvon/ caernarvon.htm). Caernarvon became operational in 1991 and was designed to moderate salinities and rein-

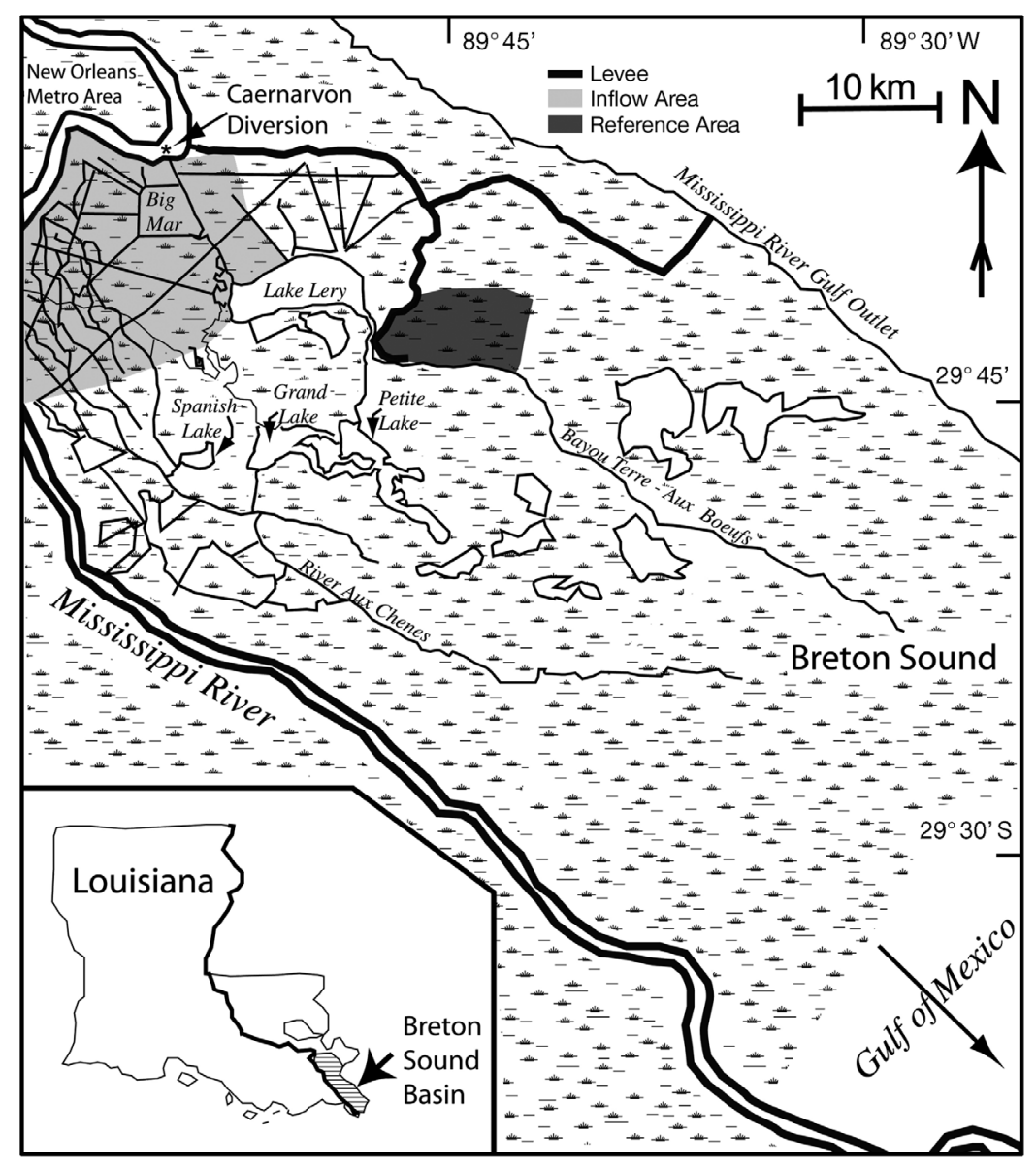

Fig. 1. Breton Sound estuary, Louisiana, USA and the location of the Caernarvon Freshwater Diversion. Shaded areas show the locations of the inflow (light gray) and reference (dark gray) areas used in this study. Map is adapted from Snedden et al. (2007b) 
troduce controlled river inflows to Breton Sound. The structure is located at the head of Breton Sound and is capable of delivering substantial amounts of fresh water $\left(227 \mathrm{~m}^{3} \mathrm{~s}^{-1}\right)$ and allochthonous sediments $(4.5 \times$ $10^{8} \mathrm{~kg} \mathrm{yr}^{-1}$ ) to the basin (Snedden et al. 2007a). Dominant emergent vegetation in upper basin marshes consists of Spartina patens (Saltmeadow cordgrass) and Schoenoplectus americanus (Chairmaker's bulrush).

Yearly experimental high-flow freshwater pulsing of the diversion structure began in spring 2001 to simulate seasonal flood-pulse events and provide opportunity for controlled experimentation. Pulses release periodic large fluxes of river water into the basin and are capable of inundating upper basin marshes ( $\sim 700 \mathrm{ha})$ for several days (Snedden et al. 2007a, $2007 a, b)$. Without the riverine pulse, inundation of upper basin marshes is dominated by meteorological forcing as occurs in marshes east of Bayou Terre Aux Boeufs, which are hydrologically separated from diversion flow (Rozas et al. 2005).

Site selection. Potential sampling sites (in the inflow and reference areas within the upper $57 \mathrm{~km}^{2}$ of the estuary) were identified using Digital Ortho Quarter Quadrangle (DOQQ) images and field reconnaissance. The area west of Bayou Terre Aux Boeufs receives diversion flow and was identified as the inflow area, and the hydrologically separated area east of the bayou was selected as the reference area.

Nekton and environmental data collection. We collected nekton samples in vegetated marsh habitat through both winter/spring pulsed freshwater releases in 2005 (February 14 to 28, March 12 to 28). Sampling was restricted to days when the marsh was flooded, resulting in more sites sampled in the inflow than reference area (Table 1). In the inflow area, flooding was a function of the time required for the experimental pulse event to flood the marsh surface. In the reference area, flooding was determined by meteorological conditions and, therefore, occurred less frequently during both pulse events.

Table 1. Number of days and sites sampled during both (February 14 to 28, March 12 to 28) Caernarvon experimental high-flow pulse events in 2005. Nekton sampling in both inflow and reference areas was restricted to days that the marsh surface was flooded. Maximum structure discharge during both pulse events was $184 \mathrm{~m}^{3} \mathrm{~s}^{-1}$

\begin{tabular}{|lcccc|}
\hline & \multicolumn{2}{c}{ February } & \multicolumn{2}{c|}{ March } \\
& Inflow & Reference & Inflow & Reference \\
\hline $\begin{array}{c}\text { Number of days } \\
\text { sampled } \\
\text { Number of sites } \\
\text { sampled }\end{array}$ & 9 & 4 & 9 & 2 \\
\hline
\end{tabular}

Sites were sampled with a $1.14 \mathrm{~m}$ cylindrical $\left(1 \mathrm{~m}^{2}\right)$ drop sampler. The drop sampler was suspended approximately $3 \mathrm{~m}$ from the bow of the boat and $1 \mathrm{~m}$ above the marsh surface by a telescoping aluminum boom. A drop sampler was chosen because it provides many advantages for sampling flooded marsh habitat including effectiveness at cutting through underground plant runners, high catch efficiency, and complete enclosure of the water column (Rozas \& Minello 1997). In addition, the telescoping boom allowed sampling in the flooded marsh 2 to $3 \mathrm{~m}$ from the edge where most nekton biomass on the marsh surface occurs (Kneib 2000). Each sampling site was approached slowly and quietly. The outboard motor was shut off, and the boat was allowed to drift to the vegetated marsh edge. In areas that were too shallow to drift, investigators quietly pushed the boat into position. Once in position, the sampler was dropped and seated securely into the marsh substrate.

After the sampler was dropped, the location of the sampler was logged with a Garmin GPS III, and a suite of environmental variables was collected inside the sampler. Water temperature $\left({ }^{\circ} \mathrm{C}\right)$, conductivity $(\mathrm{mS})$, salinity (psu), dissolved oxygen (DO, mg $\mathrm{l}^{-1}$ ), and $\mathrm{pH}$ were measured with a handheld YSI 556 MPS (YSI Environmental). Turbidity (NTU) was measured with a fluorometer (Aquafluor 8000, Turner Designs). Five water depth measurements $(\mathrm{mm})$ were taken inside the sampler with a meter stick, and hourly water depth was downloaded from nearby recorders (Inflow area-USGS 073745253, http://waterdata.usgs.gov/ usa/nwis/uv?site_no=073745253; Reference areaUSGS 073745257, http://waterdata.usgs.gov/nwis/uv ?format=gif $\&$ period $=31 \&$ site_no=073745257). Percent cover and species composition of emergent vegetation was visually estimated inside the sampler, and stems were clipped at the substrate and returned to the lab where they were identified and sorted by species and counted.

After environmental variables were measured, nekton inside the drop sampler were collected with 10 successive dip net sweeps (in opposite directions) by 2 investigators concurrently. After dip netting, retained water was pumped through a $1 \mathrm{~mm}$ mesh plankton net into a $1 \mathrm{~mm}$ mesh cod-end bag (Sea-Gear). Remaining organisms were removed from the marsh substrate by hand. Organisms were preserved in $10 \%$ formalin and returned to the laboratory for processing.

In the laboratory, samples were sorted, and nekton were identified to the lowest feasible taxon and counted. Total length of fish, shrimp, and crayfish and carapace width of crabs were measured to the nearest $\mathrm{mm}$. Individuals of each species in a sample were pooled and weighed ( $g$ wet weight) to determine biomass. 
Data analysis. Data were tested for normality with the Shapiro-Wilks test. Nekton density and biomass were $\log$ transformed to achieve normality. Data are reported as mean $\pm \mathrm{SE}$, and significance level is reported at $\alpha=0.05$, unless indicated differently.

Environmental variables: Relationships between environmental variables were investigated with correlation analysis. Differences in environmental variables (salinity, DO, temperature, stem density, turbidity, water depth) were compared by treatment (inflow and reference), experimental pulse (February and March), and interactions (Treatment $\times$ Pulse) using multivariate analysis of variance (MANOVA). Significant MANOVA models were investigated further with univariate ANOVA.

Nekton density, biomass, diversity: ANOVA (PROC MIXED) was used to test for statistical differences in density, biomass and diversity between treatments (inflow and reference marsh) and experimental pulses (February and March). Alpha $(\alpha)$ diversity was calculated with both Shannon-Wiener diversity $\left(H^{\prime}\right)$ and evenness $(E)$. Sorenson's Similarity Index $\left(\mathrm{C}_{\mathrm{s}}\right)$ was used to compare beta $(\beta)$ diversity between treatments and pulses.

Nekton communities: The C-score metric (Gotelli 2000) was used to examine community assembly dynamics in flooded habitat. This metric tests for nonrandom species assembly patterns. Using EcoSim (Gotelli \& Entsminger 2006), we calculated the C-score for an observed presence-absence matrix and tested that value against $\mathrm{C}$-score values resulting from 5000 random matrix simulations in which species occurrences (row totals) remained fixed and sites (column totals) were equiprobable (SIM2; Gotelli 2000). The SIM2 algorithm was used because it has the lowest incidence of Type I error $(<10 \%)$ with field sampling data (Gotelli 2000). Non-significant C-score values for the observed data indicate that species colonized flooded habitat randomly (independent). Observed $\mathrm{C}$-score values that are significantly less than simulated scores suggest more species co-occurrence than expected by chance (species aggregation; Stone \& Roberts 1992, Gotelli 2000). Significantly greater $\mathrm{C}$-score values suggest less species co-occurrence than expected by chance (deterministic assembly rules; Stone \& Roberts 1992, Gotelli 2000). Investigation of pairwise relationships can identify species pairs that either drive or differ from the suggested co-occurrence patterns (Arrington et al. 2005). Species were included in the C-score analysis if we caught more than 3 ind. in the samples (Gauch 1982). An initial C-score was calculated (1) for the entire data set (all sites), (2) for inflow and reference areas separately and (3) for 2 flooding durations in the inflow area: short (1 to $3 \mathrm{~d}$ ) and long ( 7 to $10 \mathrm{~d}$ ).
Canonical correspondence analysis $(\mathrm{CCA}$ CANOCO version 4.5; ter Braak \& Smilauer 2002) was used to investigate potential associations between taxa and environmental variables at all sites. CCA is a directgradient analysis that relates community-variation patterns to environmental variation. Species were included in the CCA if we caught more than 3 ind. in the samples (Gauch 1982). All environmental variables used in the MANOVA were included (salinity, DO, temperature, stem density, turbidity, water depth). Additionally, variables for each month, as well as a 'days flooded' variable were included to investigate timing effects. Environmental variables were tested for significance with 1000 Monte Carlo simulations (CANOCO 4.5; ter Braak \& Smilauer 2002).

\section{RESULTS}

\section{Environmental variables}

During 2005 experimental pulse events, the marsh was flooded for $69 \%$ (February pulse) and $64 \%$ (March pulse) of the sampling period in the inflow area and for $31 \%$ (February pulse) and 14\% (March pulse) of the sampling period in the reference area. Flooding in the reference area was driven solely by meteorological and tidal forcing throughout the study; in contrast, the freshwater inflow obscured tidal periodicity in the inflow area soon after diversion pulsing began (Fig. 2).

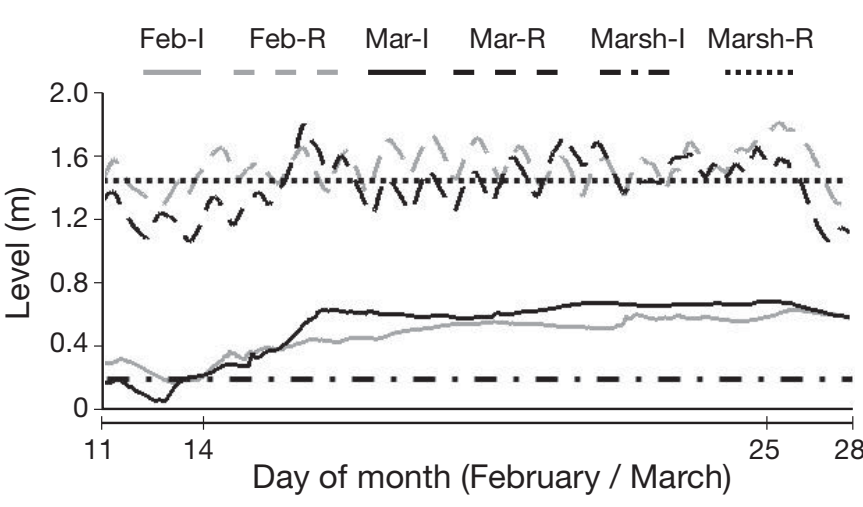

Fig. 2. Hydrograph showing water and marsh level before and during both experimental high-pulse flow events in 2005. Pulse dates were February 14-28 and March 12-28. Feb-I: February pulse inflow area; Feb-R: February pulse reference area; Mar-I: March pulse inflow area; Mar-R: March pulse reference area; Marsh-I: marsh level inflow area; Marsh-R: marsh level reference area. Source datum for stages and water level in the inflow area was the National Geodetic Vertical Datum, NGVD. Because there was no surveyed water level recorder in the reference area, stages and marsh level were based on an investigator-created datum, transferred from USGS 073745257 (http://waterdata.usgs.gov/nwis/uv?format= gif $\&$ period=31\&site_no=073745257; NGVD) 
During the February pulse, the inflow marsh was inundated $\sim 36 \mathrm{~h}$ after the diversion structure was opened. Inflow marshes dewatered completely between pulse events, and in March, marsh inundation began approximately $84 \mathrm{~h}$ after Caernarvon was opened.

Results from the MANOVA indicated a significant main-effects model for pulse $\left(F_{6,162}=23.02, \mathrm{p}<0.0001\right)$ and treatment $\left(F_{6,162}=4.90, \mathrm{p}=0.0001\right)$. A posteriori tests of main effects showed both pulse and treatment effects for salinity and DO and a Pulse $\times$ Treatment interaction effect for turbidity (Table 2 ). Water temperature and stem density showed no significant difference in main effects (Table 2). Water depth was positively correlated with stem density $(p=0.04)$ and negatively correlated with DO $(p=0.004)$ at inflow sites. When flooded, mean water depth on the marsh surface was significantly higher at inflow sites than reference sites ( $p=0.006$; Fig. 3 ).

\section{Nekton density, biomass, and diversity}

A total of $6521 \mathrm{ind}$. of 16 taxa were collected. Six resident species (Palaemonetes paludosus, Heterandria formosa, Gambusia affinis, Lucania parva, Poecilia latipinna, and Cyprinodon variegatus) comprised 95\% of the total abundance (Table 3 ). Density ranged from 0 to 485 ind. $\mathrm{m}^{-2}$ during the study. Both density $\left(F_{1,153}=\right.$ 5.35, p $=0.02$ ) and biomass (range 0 to $162.5 \mathrm{~g} \mathrm{~m}^{-2}$; $F_{1,153}=8.59, \mathrm{p}=0.003$ ) were significantly higher at inflow sites as compared to reference marsh sites (Fig. 3).

Mean Shannon diversity $\left(H^{\prime}=0.87 \pm 0.03 \mathrm{SE}\right)$ and evenness $(E=0.72 \pm 0.02 \mathrm{SE})$ did not vary by pulse or treatment (Fig. 3). Rank-abundance curves (pooled across both pulses) show that flooded inflow marsh sites were strongly dominated by a single species (geo-
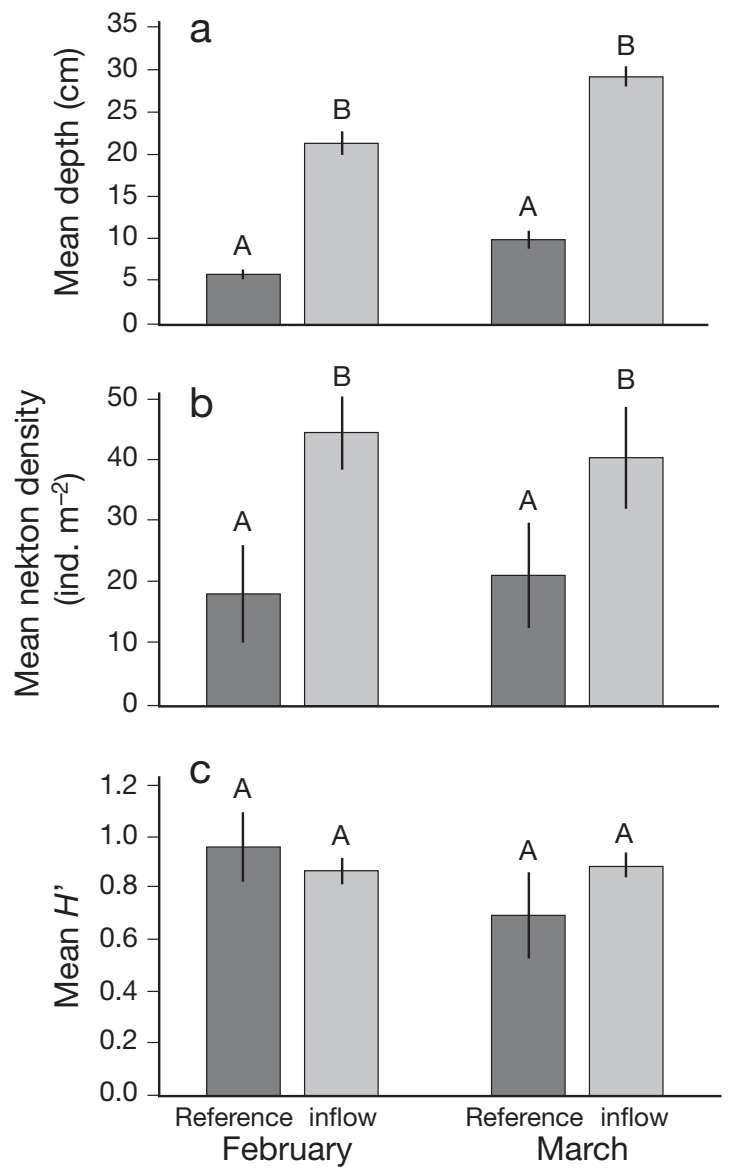

Fig. 3. (a) Water depth (cm), (b) nekton density (ind. $\mathrm{m}^{-2}$ ), and (c) Shannon-Wiener diversity $\left(H^{\prime}\right)$ at flooded marsh sampling sites during the Caernarvon experimental high-pulse flow events in 2005 (data are mean \pm SE). Samples-dark grey: reference; light grey: inflow. Capital letters denote significant statistical differences within and between pulse events. Mean biomass $\left(\mathrm{g} \mathrm{m}^{-2}\right)$ and mean Shannon-Wiener evenness, E, (both measures not shown) followed the same pattern as density and diversity, respectively

Table 2. Environmental characteristics of samples in inflow and reference areas during Caernarvon experimental highpulse flows in 2005. Data for inflow and reference areas are mean \pm SE (range). Effects $-\mathrm{P}:$ pulse; $\mathrm{T}$ : treatment. ${ }^{*} \mathrm{p}<0.05$;

$$
{ }^{* *} \mathrm{p}<0.01 i^{* * *} \mathrm{p}<0.001
$$

\begin{tabular}{|c|c|c|c|c|c|c|c|}
\hline \multirow[t]{2}{*}{ Variable } & \multicolumn{2}{|c|}{$\longrightarrow$ Inflow area -} & \multicolumn{2}{|c|}{$\longrightarrow$ Reference area -} & \multicolumn{3}{|c|}{$-F$} \\
\hline & February $(n=66)$ & $\operatorname{March}(\mathrm{n}=75)$ & February $(\mathrm{n}=18)$ & March $(\mathrm{n}=12)$ & $\mathrm{P}$ & $\mathrm{T}$ & $\mathrm{P} \times \mathrm{T}$ \\
\hline Salinity (psu) & $\begin{array}{c}0.3 \pm 0.01 \\
(0.2-0.7)\end{array}$ & $\begin{array}{c}0.2 \pm<0.01 \\
(0.2-0.2)\end{array}$ & $\begin{array}{l}1.0 \pm 0.27 \\
(0.3-4.7)\end{array}$ & $\begin{array}{c}0.7 \pm 0.07 \\
(0.3-1.0)\end{array}$ & $5.4^{*}$ & $16.2^{* * *}$ & 2.1 \\
\hline Dissolved oxygen (ppm) & $\begin{array}{c}5.7 \pm 0.22 \\
(1.8-9.4)\end{array}$ & $\begin{array}{c}2.2 \pm 0.08 \\
(1.0-4.3)\end{array}$ & $\begin{array}{c}4.4 \pm 0.57 \\
(0.9-8.3)\end{array}$ & $\begin{array}{l}1.8 \pm 0.19 \\
(1.4-3.8)\end{array}$ & $105.3^{* * *}$ & $6.0^{*}$ & 2.3 \\
\hline Water temperature $\left({ }^{\circ} \mathrm{C}\right)$ & $\begin{array}{l}17.3 \pm 0.35 \\
(11.3-23.2)\end{array}$ & $\begin{array}{l}18.4 \pm 0.50 \\
(10.5-28.1)\end{array}$ & $\begin{array}{l}18.6 \pm 0.31 \\
(15.5-21.6)\end{array}$ & $\begin{array}{l}18.5 \pm 0.84 \\
(15.6-24.6)\end{array}$ & 0.4 & 1.3 & 0.7 \\
\hline Turbidity (NTU) & $\begin{array}{c}15.9 \pm 1.14 \\
(0.8-50.0)\end{array}$ & $\begin{array}{c}14.9 \pm 1.06 \\
(0.9-38.3)\end{array}$ & $\begin{array}{c}14.1 \pm 3.65 \\
(1.7-56.3)\end{array}$ & $\begin{array}{c}23.7 \pm 5.38 \\
(3.4-60.8)\end{array}$ & 3.8 & 3.4 & $5.6^{*}$ \\
\hline Stem density (stems $\mathrm{m}^{-2}$ ) & $\begin{array}{c}117.6 \pm 19.12 \\
(0.0-618.0)\end{array}$ & $\begin{array}{c}128.6 \pm 15.77 \\
(0.0-449.0)\end{array}$ & $\begin{array}{c}167.8 \pm 38.63 \\
(0.0-512.0)\end{array}$ & $\begin{array}{c}214.9 \pm 37.72 \\
(54.0-402.0)\end{array}$ & 0.9 & 0.0 & 0.4 \\
\hline
\end{tabular}


Table 3. Mean nekton density (ind. $\mathrm{m}^{-2}$ ) by species during the February and March 2005 Caernarvon experimental high-pulse flow events in Breton Sound, Louisiana, USA. Data are mean \pm SE (SE unavailable in some cases). Gray shading indicates the species of highest density by pulse and treatment

\begin{tabular}{|c|c|c|c|c|c|c|}
\hline \multirow{2}{*}{ Species } & \multirow{2}{*}{ Common name } & \multicolumn{2}{|c|}{ Inflow area } & \multicolumn{2}{|c|}{ Reference area } & \multirow{2}{*}{$\begin{array}{c}\text { Total } \\
\text { abundance }\end{array}$} \\
\hline & & $\begin{array}{c}\text { February } \\
(\mathrm{n}=66)\end{array}$ & $\begin{array}{c}\text { March } \\
(\mathrm{n}=75)\end{array}$ & $\begin{array}{l}\text { February } \\
(\mathrm{n}=18)\end{array}$ & $\begin{array}{c}\text { March } \\
(\mathrm{n}=12)\end{array}$ & \\
\hline \multicolumn{7}{|l|}{ Fishes (total = 12 spp.) } \\
\hline Heterandria formosa & Least killifish & $12.4 \pm 2.4$ & $32.6 \pm 11.8$ & $1.0 \pm 0.0$ & $1.5 \pm 0.5$ & 1980 \\
\hline Gambusia affinis & Mosquitofish & $11.2 \pm 3.6$ & $10.5 \pm 2.2$ & $10.4 \pm 4.0$ & $4.7 \pm 2.7$ & 840 \\
\hline Lucania parva & Rainwater killifish & $8.5 \pm 2.5$ & $3.2 \pm 0.5$ & $\mathbf{1 7 . 0} \pm 12.5$ & $9.2 \pm 4.2$ & 483 \\
\hline Poecilia latipinna & Sailfin molly & $2.9 \pm 0.7$ & $2.6 \pm 0.5$ & $8.1 \pm 4.3$ & $8.8 \pm 1.6$ & 181 \\
\hline Cyprinodon variegatus & Sheepshead minnow & $2.9 \pm 0.8$ & $2.9 \pm 0.8$ & $2.0 \pm 1.0$ & $7.3 \pm 4.3$ & 107 \\
\hline Fundulus chrysotus & Golden topminnow & $1.3 \pm 0.3$ & $1.4 \pm 0.2$ & 1.0 & $1.0 \pm 0.0$ & 18 \\
\hline Lepomis macrochirus & Bluegill & $1.0 \pm 0.0$ & $1.8 \pm 0.5$ & $0.0 \pm 0.0$ & $0.0 \pm 0.0$ & 11 \\
\hline Fundulus pulvereus & Bayou killifish & 1.0 & 2.0 & $0.0 \pm 0.0$ & $1.0 \pm 0.0$ & 5 \\
\hline Lepomis punctatus & Spotted sunfish & $1.5 \pm 0.5$ & 1.0 & $0.0 \pm 0.0$ & $0.0 \pm 0.0$ & 4 \\
\hline Lepomis microlophus & Redear sunfish & $0.0 \pm 0.0$ & 2.0 & $0.0 \pm 0.0$ & $0.0 \pm 0.0$ & 2 \\
\hline Anguilla rostrata & American eel & 1.0 & $0.0 \pm 0.0$ & $0.0 \pm 0.0$ & $0.0 \pm 0.0$ & 1 \\
\hline Notropis spp. & Shiner & 1.0 & $0.0 \pm 0.0$ & $0.0 \pm 0.0$ & $0.0 \pm 0.0$ & 1 \\
\hline Pooled fishes & & $8.9 \pm 1.2$ & $13.0 \pm 3.4$ & $8.1 \pm 2.3$ & $6.1 \pm 1.5$ & 3633 \\
\hline \multicolumn{7}{|l|}{ Crustaceans (total $=4$ spp.) } \\
\hline Palaemonetes paludosus & Riverine grass shrimp & $28.8 \pm 5.3$ & $15.2 \pm 4.2$ & $13.1 \pm 6.3$ & $13.6 \pm 8.0$ & 2577 \\
\hline Cambarellus spp. & Crayfish & $2.8 \pm 0.4$ & $2.9 \pm 0.4$ & 1.0 & $0.0 \pm 0.0$ & 174 \\
\hline Procambarus spp. & Crayfish & $2.2 \pm 0.3$ & $2.3 \pm 0.3$ & $1.5 \pm 0.3$ & $1.0 \pm 0.0$ & 134 \\
\hline Calinectes sapidus & Blue crab & 2.0 & 1.0 & $0.0 \pm 0.0$ & $0.0 \pm 0.0$ & 3 \\
\hline Pooled crustaceans & & $15.8 \pm 3.0$ & $8.3 \pm 2.0$ & $8.6 \pm 4.1$ & $11.1 \pm 6.5$ & 2888 \\
\hline
\end{tabular}

metric pattern of species abundance), while flooded marsh sites in reference marshes were less single-species dominated, showing closer to a log-normal pattern of species abundance (Fig. 4). The dominant species at inflow sites switched, from Palaemonetes paludosus during the February pulse to Heterandria formosa during the March pulse (Table 3). With the exception of some rare species, assemblages were similar during both 2005 February and March pulses (13 species in common; $\left.\mathrm{C}_{\mathrm{s}}=0.90\right)$. Assemblages were less similar between reference and inflow areas (10 common species; $\mathrm{C}_{\mathrm{s}}=0.77$ ), largely due to the lack of Centrarchids (Lepomis spp.) at reference sites.

\section{Nekton community assembly}

C-score analysis

Results of the C-score analysis for the entire data set indicated significantly more co-occurrence than expected by chance $\left(\mathrm{C}_{\mathrm{obs}} 491.9, \mathrm{C}_{\mathrm{sim}} 608.4 ; \mathrm{p}<0.0001\right)$ and were likely largely driven by the dominance of resident species in the assemblages. This relationship was found for both reference $\left(\mathrm{C}_{\text {obs }}=11.4, \mathrm{C}_{\text {sim }}=32.0\right.$; $\mathrm{p}<0.0001)$ and inflow treatments $\left(\mathrm{C}_{\mathrm{obs}}=491.3, \mathrm{C}_{\mathrm{sim}}=\right.$ 545.0; p $<0.003$ ), as well as for sites continuously flooded for 7 to $10 \mathrm{~d}$ during each pulse $\left(\mathrm{C}_{\mathrm{obs}}=35.0\right.$, $\left.\mathrm{C}_{\text {sim }}=43.4 ; \mathrm{p}<0.001\right)$. Non-significant $\mathrm{C}$-score values

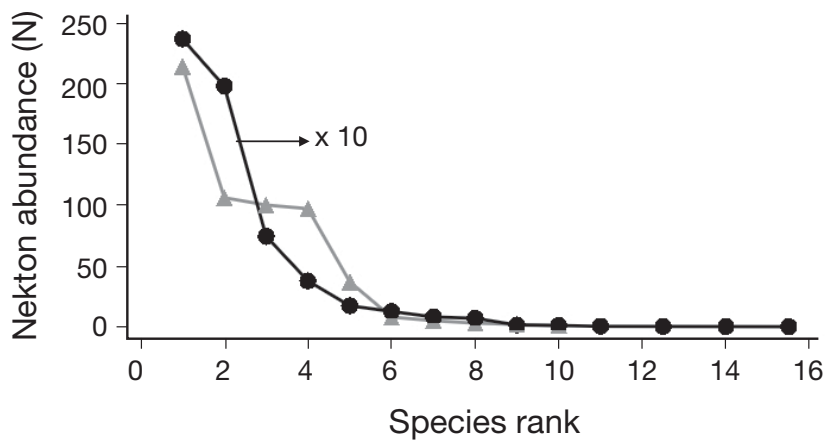

Fig. 4. Species rank curves for nekton assemblages caught at flooded marsh sampling sites during the Caernarvon experimental high-pulse flow events in 2005. Samples-black: inflow; grey: reference. Nekton abundance for inflow samples was an order of magnitude higher than the $y$-axis

for the observed data were found for sites flooded for short duration ( 1 to $3 \mathrm{~d}$ ), indicating random colonization of flooded habitat at those sites. Investigation of pairwise species scores for the entire data set revealed particularly high C-scores for Palaemonetes paludosus and Heterandria formosa (1000.0), P. paludosus and Gambusia affinis (900.0), H. formosa and Poecilia latipinna (1190.0), H. formosa and Lucania parva (1325.0), and L. parva and G. affinis (1598.0), suggesting that, even though these species largely co-exist, they were segregating, at least some of the time. 
Canonical correspondence analysis

Correlation analysis showed a significant positive relationship ( $\mathrm{p}=0.002$ ) between water depth and days flooded. Therefore, only water depth was included in the full model. Forward selection of environmental variables for CCA analysis of all sites showed that water depth $(F=21.25, \mathrm{p}=0.001)$, DO $(F=5.50, \mathrm{p}=0.001)$, and salinity $(F=3.62, \mathrm{p}=0.03)$ were statistically significant. The first 2 axes represented $94 \%$ of the speciesenvironment relationship. Axis 1 was largely a depth axis, correlated positively to water depth (0.64). Axis 2 correlated most strongly with salinity (0.35). DO was influential on both axes (Axis $1=-0.34$, Axis $2=-0.31$ ). Investigation of the species-environment relationships (Fig. 5) shows that a number of the dominant species (Poecilia latipinna, Cyprinodon variegatus, Palaemonetes paludosus, and Lucania parva) were associated negatively with depth. $P$. latipinna also associated closely with salinity. Conversely, Heterandria formosa associated strongly and positively with depth.

Further investigation of the top 6 species in relation to depth (Fig. 6) reveals a difference in abundances

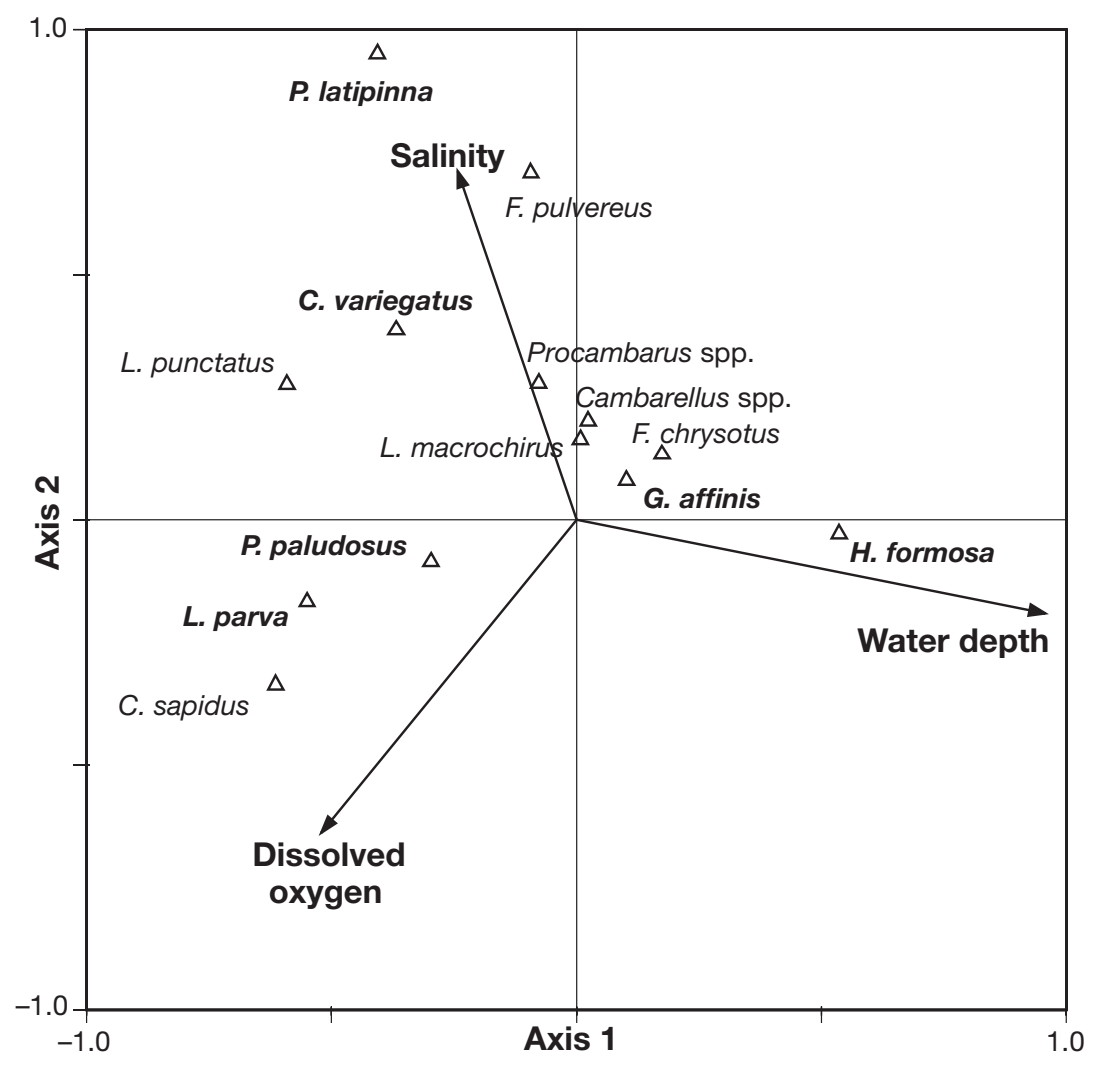

Fig. 5. Association of environmental variables and nekton species based on canonical correspondence analysis for all sites in Breton Sound estuary through 2 (February and March) high-flow pulse events of the Caernarvon Freshwater Diversion structure in 2005. Displayed environmental variables are statistically significant at $\alpha=0.05$. Bold: dominant species (see Table 3 for full names) with depth. Highest abundances of Palaemonetes paludosus, Lucania parva, Poecilia latipinna and Cyprinodon variegatus were found at shallower sites, and both Gambusia affinis and Heterandria formosa were found in highest abundances at deeper sites.

\section{DISCUSSION}

This study documented higher nekton densities and biomasses in marshes receiving high-volume freshwater flow than in marshes not receiving pulsed flow. Differences in density and biomass were attributed mostly to differences in water depth and flooding duration caused by the pulses. Communities were largely similar and consisted mainly of marsh resident species. An examination of individual species also revealed an apparent habitat preference related to water depth.

\section{Water depth and flooding duration}

Though marsh inundation events occurred at both the inflow area and the reference area, water depth and inundation periods were greater for marshes in the inflow area during the 2005 experimental freshwater pulses. Throughout Breton Sound, estuarine water levels respond to meteorologically-induced fluctuations outside the estuary over the continental shelf (Snedden et al. 2007b). Fluctuations of this nature comprise most of the subtidal sea level variability in regions outside the diversion's influence. Closer to the diversion, variability attributable to freshwater inputs through Caernarvon exceeds that attributable to meteorological forcing, and this dynamic is reflected in the greater flood durations observed at inflow sites.

Unlike the deterministic semi-diurnal tidal inundation regimes of typical East Coast coastal marshes, flooding events in Breton Sound are driven by relatively stochastic processes that occur over longer timescales: (1) meteorological forcing (4 to $7 \mathrm{~d}$; Chuang \& Wiseman 1983); (2) a semi-annual continental shelf sea-level regime that is primarily composed of seasonal patterns in wind forcing and thermosteric sea level fluctuations (Current 1996); 

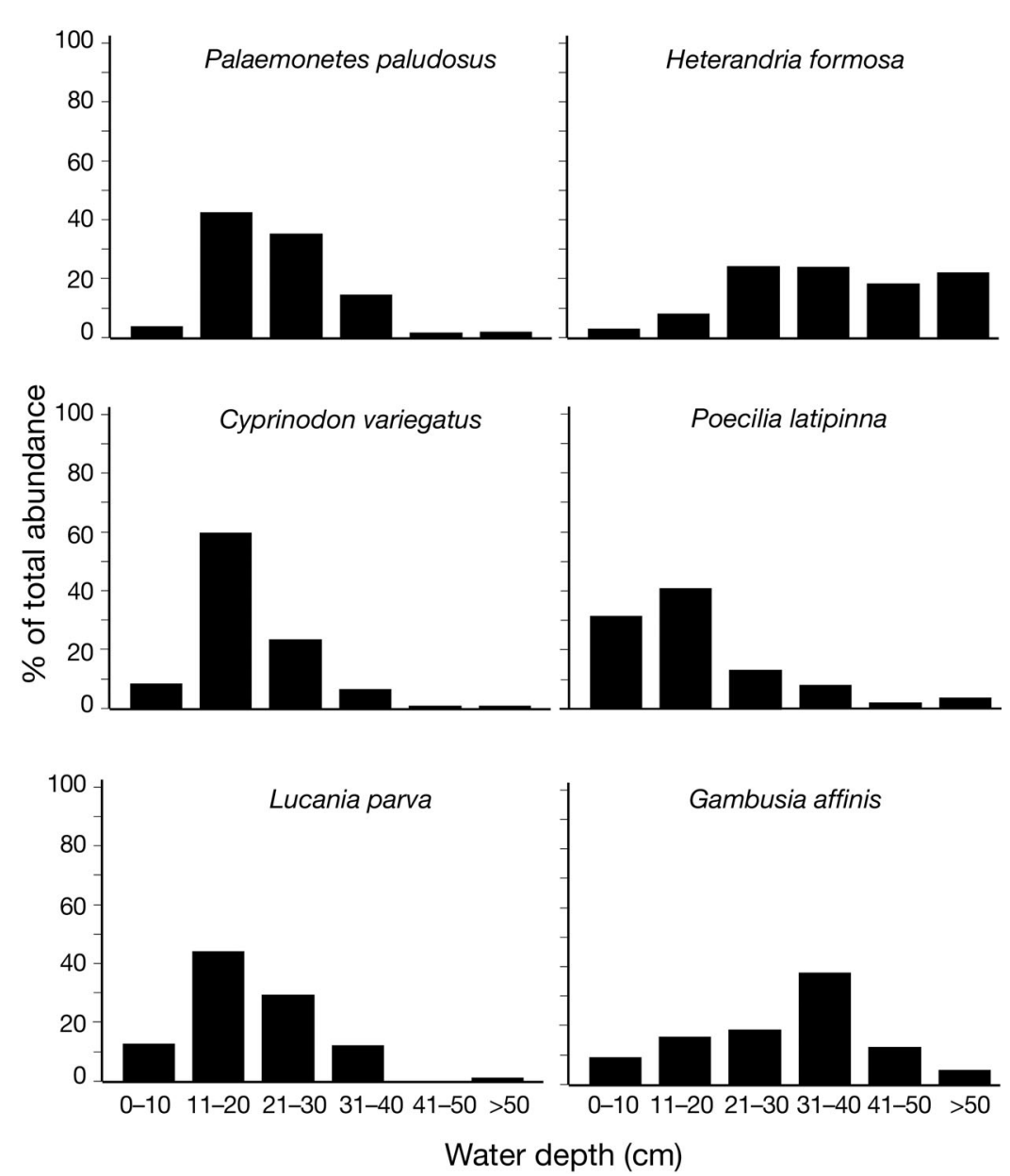

Fig. 6. Top 6 nekton species abundances as a function of water depth during Caernarvon experimental pulse events. Samples from all sites (inflow and reference) and pulse events (February and March) were combined

and (3) pulsed freshwater releases of Mississippi River water through Caernarvon (14 d). In our study, these pulses of river water contributed to inundation times in the inflow area that were twice that observed in the reference area, as well as provided enhanced nekton access to marsh overflow habitats, and increased the potential residence time in these habitats. Nekton do not appear to be negatively impacted by the relatively stochastic flooding regime as some of the highest densities of estuarine nekton in North America are reported for Gulf coast estuaries (Rozas 1995). This may be due to the fact that once on the marsh surface, nekton can occupy the habitat for long periods of time.

\section{Nekton densities}

Increased flooding depth and duration at inflow marsh sites were associated with higher densities (>40 ind. $\left.\mathrm{m}^{-2}\right)$ than reference marsh sites $\left(\sim 15\right.$ ind. $\left.\mathrm{m}^{-2}\right)$ in our study, and in comparable studies of nekton densities in flooded marsh habitat (i.e. Rozas et al. 2005). When comparing studies, the effects of (1) location, (2) timescale of flooding (i.e. prolonged river-induced vs. diurnal flooding), (3) timing, and (4) gear-type (abundance vs. density) all need to be considered. The closest comparable study (Rozas et al. 2005) used a drop sampler in Breton Sound to investigate pulsing effects from Caernarvon and found total mean nekton densities of approximately 20 ind. $\mathrm{m}^{-2}$ in vegetated shoreline habitat downstream (inflow area) from the Caernarvon diversion in May 2001, following pulsed freshwater releases earlier in the season. Rozas et al.'s (2005) study primarily investigated salinity effects of pulsing and took place farther down basin than our study and at a time when marsh flooding was largely forced by meteorological tides. In another Louisiana study, Castellanos \& Rozas (2001) used a $1 \mathrm{~m}^{2}$ throw trap and found densities of over 30 ind. $\mathrm{m}^{-2}$ at sites vegetated with Schoenoplectus americanus in flooded backmarsh habitat on the Atchafalaya River delta. Because their study took place during summer, a time when Atchafalaya River discharge is typically low, the effects of pulsed freshwater delivery were not examined. Rather, their study focused on tidal flooding by marine processes (Ekman transport and thermal expansion of water). In Georgia, Kneib (1997) used simulated aquatic microhabitats to collect nekton during ebb tides in flooded saltmarsh sites on Sapelo Island. He reported mean densities of 11.7 ind $\mathrm{m}^{-2}$ and estimated densities of marsh residents ranging from 1.8 to 16.7 ind. $\mathrm{m}^{-2}$ in flooded intertidal marsh sites. In 2 studies using a $1 \mathrm{~m}^{2}$ throw trap in the Florida Everglades, Green et al. (2006) reported mean densities of 6.6 ind. $\mathrm{m}^{-2}$ at freshwater sites in the Taylor River drainage, and Williams \& Trexler (2006) documented mean fish densities of 21.6 ind $\mathrm{m}^{-2}$ (range 5.0-42.0 ind. $\mathrm{m}^{-2}$ ) in freshwater marsh during the wet season (June to September).

Because our study took place during late winter and early spring, the link between riverine input and nekton densities is more apparent. Studies that track nekton densities during this time of year in the Gulf of Mexico (i.e. February, March) are rare, as most, such as those mentioned above, examine the period from late spring to early fall, when nekton densities on the marsh 
are typically highest. However, studies that have tracked abundances throughout the year typically found that relative abundances were lowest during the late winter/early spring. For example, one study found that individuals captured during February and March comprised only $2.5 \%$ of the annual catch (Kneib 1997), and considering the reported annual mean for that study was 11.7 ind. $\mathrm{m}^{-2}$ in flooded saltmarsh sites, this represents very low mean densities during early spring. The low densities reported by Kneib (1997) may have been an artifact of lower water levels and nekton aggregation in deeper and warmer habitats.

In our study, flooded marsh sites downstream from the diversion had higher nekton densities and biomasses than flooded marsh sites not receiving diversion flow, possibly due to greater access (i.e. water depth and duration of flooding) to the marsh surface in the inflow area. This finding is consistent with other studies that investigated effects of freshwater flow on estuarine fauna. Montagna \& Kalke (1992) found that average density and biomass of benthic macrofauna in samples in the Guadalupe Estuary (high freshwater input) were significantly higher than those in the Nueces Estuary (low freshwater input), and differences in species assemblages in these Texas (USA) estuaries corresponded to freshwater inputs. In Brazil, Barletta et al. (2005) found highest mean values for nekton density and biomass in upper Caeté River estuary sites during the rainy season when freshwater inputs were highest.

\section{Nekton diversity and community assembly}

The number of species caught in our study was relatively low for this habitat type, likely due to the time of year. In comparison with other studies of tidal freshwater marsh during peak seasons (e.g. Rozas \& Odum 1987, Castellanos \& Rozas 2001, Green et al. 2006), we caught about half the number of species and lacked transient species that occupy the marsh surface later during the season. The resident species in our study comprise a guild of omnivores that rapidly colonize the marsh surface once it is inundated, feeding on detritus, epiphytic bacteria, insect larvae, and infauna (Kneib 1997, 2000). These species potentially derive a significant growth and safety benefit by quickly colonizing and remaining on the flooded marsh surface. Within a guild, there is often competition for similar food supplies (Stone \& Roberts 1992). However, results of the C-score tests indicated that deterministic processes (e.g. competition) were not affecting community assembly. Rather, our results support the coexistence principle (Stone \& Roberts 1992), which states that ecologically closely related species derive benefit from coexistence that outweigh the costs imposed by high within-guild competition for resources. Therefore, ecologically-related species should be found at the same sites more often than by chance. Interestingly, even within this guild that presumably benefits from coexistence, there was evidence of species stratification, and the discriminating factor appeared to be water depth.

Between treatments, assemblage differences were largely due to the lack of predatory species (Lepomis spp.) at flooded reference sites. This may be due to the lack of consistent flooding, shallow water depth, and short flooding duration at reference sites, which did not allow time for predator colonization of the marsh surface. Rypel et al. (2007) examined predation risk for a highly motile prey fish species in relation to water depth in Bahamanian tidal creeks and classified a zone of prey refugia ( 0 to $19 \mathrm{~cm}$ ), where prey were eaten by predators only $2 \%$ of the time, as compared to their deepest sites where prey were eaten $100 \%$ of the time $(>70 \mathrm{~cm})$. Although their depth zones are not directly comparable to our study, what is clear is that depths recorded in flooded reference marshes in our study were likely too shallow for occupation by predatory fishes, while water depths in flooded inflow marshes may have become deep enough to enhance predator colonization, but few were found, even at the deepest sites. Perhaps in our study, predators avoided the deepest sites because deeper sites had more emergent vegetation, and foraging efficiency of piscivores can be limited by dense vegetation (Ruiz et al. 1993).

Several studies have investigated habitat selection of estuarine nekton in relation to water depth and have concluded that nekton assembly to the marsh surface is non-random and may be driven by biotic interactions (Ruiz et al. 1993, Bretsch \& Allen 2006a,b). In a study in a South Carolina (USA) salt marsh, Bretsch \& Allen (2006a) found that peak flood migration for resident species occurred at depths under $40 \mathrm{~cm}$, and peak migration for the 2 most abundant residents (Palaemonetes pugio and Fundulus heteroclitus) occurred between 10 and $20 \mathrm{~cm}$ water depth. Assembly of residents in our study was largely similar, as peak abundance for 5 ( $P$. paludosus, Cyprinodon variegatus, Poecilia latipinna, Lucania parva, Gambusia affinis) of the 6 dominant residents was found at water depths $<40 \mathrm{~cm}$. Of these 5 species, G. affinis abundance was different and peaked at the deep end of this range. Although our study did not investigate possible mechanisms controlling habitat selection, avian predation has been cited as a possible factor in selection for deeper habitat by prey fish, especially larger-bodied species (Bretsch \& Allen 2006a,b). It is also possible that $G$. affinis selected deeper water depths for breeding. Ruetz et al. (2005) reported a synchrony of assembly with depth for $G$. holbrooki and attributed it to in situ breeding, rather than dispersal. This mechanism 
also could explain the strong assembly pulse at deep water sites shown by Heterandria formosa.

Heterandria formosa was consistently found in large numbers $\left(>30\right.$ ind. $\left.\mathrm{m}^{-2}\right)$ at deeper water sites $(>50 \mathrm{~cm})$, suggesting a possible coupling of this species with freshwater pulsing. These densities were very high as this species is not usually numerically dominant in Louisiana studies (e.g. see Castellanos \& Rozas 2001). However, this colonization pattern agrees with those found for $H$. formosa in the Florida Everglades, where this species recovers slowly after marsh drydown events and is consistently more abundant at longhydroperiod sites than at short-hydroperiod sites (Trexler et al. 2002, DeAngelis et al. 2005, Ruetz et al. 2005). Seasonal timing did not appear to be a factor in the abundance pattern because we did not see a similar pulse in $H$. formosa abundances in the reference area that mirrored the inflow area. In fact, $H$. formosa was completely absent from reference sites during February and was also largely absent from reference sites during the March pulse. Additionally, observations of this tiny fish species at deep water sites does not agree with work that shows positive relationships between body size and depth for estuarine resident and transient fish species (Bretsch \& Allen 2006a), which suggests predation as a dominant control factor. More likely, this assembly pulse of $H$. formosa at deep water sites in the inflow area may signify a coupling between freshwater pulsing and breeding that is attributable to the increased depth and duration of flooding in the inflow area. Although we did not study this mechanism, phenotypic plasticity in breeding behavior is commonly seen in variable environments (Schaffer 1974) and specifically in Poeciliidae (Thibault \& Schultz 1978). Additionally, in the Everglades, population dynamics of $H$. formosa were attributed to a Moran effect, synchronized by water depth, and recolonization of this and other Moran-controlled species (e.g. Gambusia holbrooki) was attributed to in situ reproduction and not dispersal (Ruetz et al. 2005).

Our results suggest that freshwater pulsing may enhance secondary productivity in the Breton Sound estuary; increased nekton density, biomass and community assembly were directly attributed to factors associated with marsh-surface flooding. However, when reporting results such as these, the question always arises whether increased abundances are the result of increased habitat availability (build it and they will come) or because of increased habitat quality (e.g. nutrient enrichment) from riverine input. In the case of Breton Sound, evidence has been reported for both rapid uptake of nutrients $\left(\mathrm{N}\right.$ and $\mathrm{P}_{\text {; }}$ Lane et al. 2004) and transfer of the riverine nutrients into resident species (Palaemonetes spp.) downstream from pulsed riverine input (Rozas et al. 2005). Additionally, in our study, we repeatedly observed red drum Sciaenops ocellatus, a predator, swimming along flooded marsh edges in fresh water directly downstream from the diversion. The presence of upper trophic level predators such as red drum in these areas suggests a benefit from concentrated prey resources. However, to properly evaluate freshwater pulsing as an energy producer, we must quantify its energetic value, and very few studies have done this, especially for resident species (Stevens et al. 2006). The results of our study provide the first step toward quantifying the potential energetic subsidy of the freshwater pulse to downstream habitats in the form of resident nekton.

Acknowledgements. S. Hillen (JHT) and L. Rozas (NOAA Fisheries Service) provided technical assistance and field support. C. Cannaday, W. Cochran, B. Gossman, S. Piazza, A. Piehler, M. Piehler, S. Pierliuissi, and A. Podey provided field assistance. M. Fischer (IAP Worldwide Services) provided technical assistance in the preparation of the manuscript. M. Benge and M. Farizo (Delacroix Corporation) provided land access rights, lodging, and support of LSU coastal research. C. Villarubia, T. Bernhard (Louisiana Department of Natural Resources), L. Serpas (Plaquemines Parish) and the Caernarvon Interagency Advisory Committee provided experimental freshwater pulses. T. Minello (NOAA Fisheries Service), S. Piazza (USGS), and G. Snedden (USGS) reviewed the manuscript. This work was funded by the Louisiana Governor's Applied Coastal Research and Development Program and was conducted in accordance with institutional, national and international guidelines concerning the use of animals in research (Louisiana State University Institutional Animal Care and Use Protocol \#05-008).

\section{LITERATURE CITED}

Alber M (2002) A conceptual model of estuarine freshwater inflow management. Estuaries 25:1246-1261

Arrington DA, Winemiller KO, Layman CA (2005) Community assembly at the patch scale in a species rich tropical river. Oecologia 144:157-167

Barletta M, Barletta-Bergen A, Saint-Paul U, Hubold G (2005) The role of salinity in structuring the fish assemblages in a tropical estuary. J Fish Biol 66:45-72

Barras JA, Beville S, Britsch D, Hartley S and others (2003) Historical and projected coastal Louisiana land changes: 1978-2050. United States Geological Survey Report No. 03-334. Available at: www.nwrc.usgs.gov/special/ NewHistoricalland.pdf

Bretsch K, Allen DM (2006a) Tidal migrations of nekton in salt marsh intertidal creeks. Estuar Coasts 29:474-486

Bretsch K, Allen DM (2006b) Effects of biotic factors on depth selection by salt marsh nekton. J Exp Mar Biol Ecol 334: 130-138

Browder JA, Moore D (1981) A new approach to determining the quantitative relationship between fishery production and flow of fresh water to estuaries. In: Cross R, Williams D (eds) Nat Symp on Freshwater Inflow to Estuaries. US Department of the Interior, US Fish and Wildlife Service, Washington, DC, p 403-450

Castellanos DL, Rozas LP (2001) Nekton use of submerged aquatic vegetation, marsh, and shallow unvegetated bot- 
tom in the Atchafalaya River Delta, a Louisiana tidal freshwater ecosystem. Estuaries 24:184-197

Chuang WS, Wiseman WJ Jr (1983) Coastal sea level response to frontal passages on the Louisiana-Texas shelf. J Geophys Res 88:2615-2620

Current CL (1996) Spectral model simulation of wind driven subinertial circulation on the inner Texas-Louisiana shelf waters of the northern Gulf of Mexico. PhD dissertation, Texas A\&M University, College Station, TX

DeAngelis DL, Trexler JC, Loftus WF (2005) Life history tradeoffs and community dynamics of small fishes in a seasonally pulsed wetland. Can J Fish Aquat Sci 62:781-790

Gauch HG Jr (1982) Multivariate analysis in community ecology. Cambridge University Press, Cambridge

Gillanders BM, Kingsford MJ (2002) Impact of changes in flow of freshwater on estuarine and open coastal habitats and the associated organisms. Oceanogr Mar Biol Annu Rev 40:233-309

Gotelli NJ (2000) Null model analysis of species co-occurrence patterns. Ecology 81:2606-2621

Gotelli NJ, Entsminger GL (2006) EcoSim: null models software for ecology. Version 7. Acquired Intelligence Inc. \& Kesey-Bear, Jericho, VT

Green D, Trexler JC, Lorenz JJ, McIvor CC, Philippi T (2006) Spatial patterns of fish communities along two estuarine gradients in south Florida. Hydrobiologia 569:387-399

Kneib RT (1997) Early life stages of resident nekton in intertidal marshes. Estuaries 20:214-230

Kneib RT (2000) Salt marsh ecoscapes and production transfers by estuarine nekton in the southeastern United States. In: Weinstein MP, Kreeger DA (eds) Concepts and controversies in tidal marsh ecology. Kluwer, Boston, MA, p 267-291

Kushlan JA (1976) Environmental stability and fish community diversity. Ecology 57:821-825

Lane RR, Day JW, Justic D, Reyes E, Marx B, Day JN, Hyfield $\mathrm{E}$ (2004) Changes in stoichiometric $\mathrm{Si}, \mathrm{N}$ and $\mathrm{P}$ ratios of Mississippi River water diverted through coastal wetlands to the Gulf of Mexico. Estuar Coast Shelf Sci 60:1-10

Loneragan NR, Bunn SE (1999) River flows and estuarine ecosystems: implications for coastal fisheries from a review and a case study of the Logan River, southeast Queensland. Aust J Ecol 24:431-440

Montagna PA, Kalke RD (1992) The effect of freshwater inflow on meiofaunal and macrofaunal populations in the Guadalupe and Nueces estuaries, Texas. Estuaries 15: 307-326

Rozas LP (1995) Hydroperiod and its influence on nekton use of the salt marsh: a pulsing ecosystem. Estuaries 18:579-590

Rozas LP, Minello TJ (1997) Estimating densities of small fishes and decapod crustaceans in shallow estuarine habitats: a review of sampling design with focus on gear selection. Estuaries 20:199-213

Editorial responsibility: Sean Connell (Contributing Editor), Adelaide, South Australia, Australia
Rozas LP, Odum WE (1987) The role of submerged aquatic vegetation in influencing the abundance of nekton on contiguous tidal fresh-water marshes. J Exp Mar Biol Ecol 114: 289-300

Rozas LP, Minello TJ, Munuera-Fernandez I, Fry B, Wissel B (2005) Macrofaunal distributions and habitat change following winter-spring pulsed releases of freshwater into the Breton Sound estuary, Louisiana. Estuar Coast Shelf Sci 65: 319-336

Ruetz CR III, Trexler JC, Jordan F, Loftus WF, Perry SA (2005) Population dynamics of wetland fishes: spatio-temporal patterns synchronized by hydrological disturbance? J Anim Ecol 74:322-332

Ruiz GM, Hines AH, Posey MH (1993) Shallow water as refuge for fish and crustaceans in non-vegetated estuaries. Mar Ecol Prog Ser 99:1-16

Rypel AL, Layman CA, Arrington DA (2007) Water depth modifies relative predation risk for a motile fish taxon in Bahamanian tidal creeks. Estuar Coasts 30:518-525

Schaffer WM (1974) Optimal reproductive effort in fluctuating environments. Am Nat 108:783-790

Snedden GA, Cable JE, Swarzenski C, Swenson E (2007a) Sediment discharge into a subsiding Louisiana deltaic estuary through a Mississippi River diversion. Estuar Coast Shelf Sci 71:181-193

Snedden GA, Cable JE, Wiseman WJ (2007b) Subtidal sea level variability in a Mississippi River deltaic estuary, Louisiana. Estuar Coast 30:(in press)

Stevens PW, Montague CL, Sulak KJ (2006) Fate of fish production in a seasonally flooded saltmarsh. Mar Ecol Prog Ser 327:267-277

Stone L, Roberts A (1992) Competitive exclusion, or species aggregation? Oecologia 91:419-424

ter Braak CJF, Smilauer P (2002) CANOCO Reference manual and CanoDraw for Windows user's guide: software for canonical community ordination (version 4.5). Microcomputer Power, Ithaca, NY

Thibault RE, Schultz RJ (1978) Reproductive adaptations among viviparous fishes (Cyprinodontiformes: Poeciliidae). Evolution 32:320-333

Trexler JC, Loftus WF, Jordan F, Chick JH, Kandl KL, McElroy TC, Bass OL Jr (2002) Ecological scale and its implications for freshwater fishes in the Florida Everglades. In: Porter JW, Porter KG (eds) The Everglades, Florida Bay, and coral reefs of the Florida Keys: an ecosystem sourcebook. CRC Press, Boca Raton, FL, p 153-180

Williams AJ, Trexler JC (2006) A preliminary analysis of the correlation of food-web characteristics with hydrology and nutrient gradients in the southern Everglades. Hydrobiologia 569:493-504

Winemiller KO, Jepsen DB (1998) Effects of seasonality and fish movement on tropical river food webs. J Fish Biol 53: $267-296$

Submitted: August 15, 2007; Accepted: October 15, 2007 Proofs received from author(s): November 2, 2007 